УДК 006.82:629.5.035:620.22

\author{
Т.В. Кімстач ${ }^{1}$, К.І. Узлов ${ }^{1}$, С.І. Реп' ${ }^{1}{ }^{1}$, Л.І. Солоненко ${ }^{2}$ \\ ${ }^{1}$ Національна металургійна академія України \\ ${ }^{2}$ Одеський національний політехнічний університет
}

\title{
АНАЛІЗ НОРМАТИВНИХ ВИМОГ ДО МАТЕРІАЛУ ДЛЯ ВИГОТОВЛЕННЯ ГРЕБНИХ ГВИНТІВ
}

\begin{abstract}
Розглянуто вимоги щодо механічних властивостей матеріалу гребних гвинтів, умов та особливостей їх експлуатації. Розглянуто відмінності щодо властивостей сплавів для гребних гвинтів, які експлуатують в різних кліматичних умовах та воді з різної концентрацією розчинених домішок. Проаналізовано сучасні тенденції до підвищення їх якості. Визначені ефективні напрями удосконалення складів та технологій обробки сплавів для виготовлення гребних гвинтів морських суден. Надана актуальна інформація щодо проблеми підвищення надійності та довговічності роботи гребних гвинтів, одним 3 методів вирішення якої є цілеспрямований вибір матеріалу для їх виготовлення. Запропоновані у якості перспективних матеріалів для виготовлення виконавчих рушійних елементів морських суден алюмінієві бронзи з аргументовано обгрунтованою кількістю легуючих домішок.
\end{abstract}

DOI: $10.34185 / 0543-5749.2020-3-28-38$

\section{Вступ}

В останні десятиліття до надводних і підводних кораблів пред'являються підвищені вимоги по надійності, економічності їх обслуговування в процесі експлуатації і зниження їх собівартості в цілому. Аналогічні вимоги пред'являють до всіх складових і комплектуючих суден, до додаткового і допоміжного устаткування, у тому числі до гребних гвинтів.

Розвиток сучасного суднобудування, яке характеризується збільшенням водотоннажності суден, потужності їх двигунів і швидкості ходу, диктує жорсткі вимоги до рівня шуму і вібрації при русі, а також до експлуатаційної надійності гребних гвинтів.

3 урахуванням особливостей виробництва i експлуатації гребних гвинтів матеріали для їх виготовлення повинні мати такі загальні властивості [1 - 3]:

- високі механічні властивості - мі-

цність і пластичність, які забезпечують можливість протистояти втомним навантаженням, що сприймають лопаті;
- підвищена корозійна i ерозійна стійкість та здатність зберігати первинну чистоту поверхні тривалий час;

- кавітаційна стійкість, яка забезпечує опір руйнуванню при дії гідравлічних ударів;

- високі технологічні і задовільні ливарні властивості;

- ремонтопридатність - здатність легко піддаватися правці, заварюванню, наплавленню і т. д.

\section{Мета роботи}

На підставі порівняльного аналізу нормативних вимог до використовуваних матеріалів визначити перспективні напрями удосконалення складів та технологій обробки сплавів для виготовлення гребних гвинтів річкових та морських суден.

3 урахуванням одержаних даних, встановити перспективні матеріали та шляхи підвищення надійності і довговічності роботи виробів для судноплавства.

(C) Кімстач Т.В., Узлов К.І., Реп'ях С.І., Солоненко Л.І., 2020 


\section{Постановка проблеми та аналіз шляхів її вирішення}

Відповідно до ГОСТ 8054-81 [4] для виготовлення гребних гвинтів, в залежності від призначення судна, рекомендується застосовувати такі матеріали: спеціальні бронзи, спеціальні латуні, нержавіючі і вуглецеві сталі (табл. 1).

Механічні властивості матеріалів, що застосовують для виготовлення гребних гвинтів і лопатей, повинні бути не нижче показників наведених в таблиці 2 [4].

3 огляду на дефіцитність кольорових сплавів і високу вартість неіржавчої сталі гребні гвинти річкових і озерних судів рекомендовано виготовляти 3 вуглецевих сталей марок 25Л, 30Л і 35Л. Хімічний склад сталей наведено в таблиці 3 [5].

Таблиця 1. Класи гребних гвинтів за ГОСТ 8054-81

\begin{tabular}{|c|c|c|}
\hline Клас гребного гвинта & Матеріал гребного гвинта & Області застосування \\
\hline Особливий & $\begin{array}{l}\text { Спеціальні сплави, спеціальні } \\
\text { бронзи, нержавіючі сталі }\end{array}$ & $\begin{array}{l}\text { Судна морські швидкохідні, внутріш- } \\
\text { нього плавання }\end{array}$ \\
\hline Вищий & $\begin{array}{l}\text { Спеціальні сплави, спеціальні } \\
\text { бронзи, спеціальні латуні, } \\
\text { нержавіючі сталі }\end{array}$ & $\begin{array}{l}\text { Судна морські, внутрішнього плавання, } \\
\text { рибопромислового флоту необмеженого } \\
\text { району плавання }\end{array}$ \\
\hline Середній & $\begin{array}{l}\text { Спеціальні сплави, спеціальні } \\
\text { бронзи, спеціальні латуні, } \\
\text { сталі неіржавчі та вуглецеві }\end{array}$ & $\begin{array}{l}\text { Судна морські, внутрішнього плавання, } \\
\text { шлюпки зі швидкістю ходу менш ніж } \\
15 \text { вузлів }\end{array}$ \\
\hline Звичайний & $\begin{array}{l}\text { Спеціальні сплави, спеціальні } \\
\text { бронзи, спеціальні латуні, } \\
\text { нержавіючі сталі, вуглецеві } \\
\text { сталі }\end{array}$ & $\begin{array}{l}\text { Судна і плавучі засоби морські, для } \\
\text { яких швидкість ходу не є визначальним } \\
\text { параметром, судна внутрішнього пла- } \\
\text { вання }\end{array}$ \\
\hline
\end{tabular}

Таблиця 2. Механічні властивості матеріалів, що застосовують для виготовлення гребних гвинтів і лопатей за ГОСТ 8054-81

\begin{tabular}{|c|c|c|c|c|c|c|}
\hline $\begin{array}{c}\text { Матеріал гребного } \\
\text { гвинта }\end{array}$ & $\begin{array}{c}\text { Тимчасовий } \\
\text { опір розриву, } \\
\sigma_{\text {в }}, \text { МПа }\end{array}$ & $\begin{array}{c}\text { Умовна } \\
\text { межа } \\
\text { плинності, } \\
\sigma_{0,2}, \text { МПа }\end{array}$ & $\begin{array}{c}\text { Відносне } \\
\text { подовження, } \\
\delta_{5}, \%\end{array}$ & $\begin{array}{c}\text { Відносне } \\
\text { звуження, } \\
\psi, \%\end{array}$ & $\begin{array}{c}\text { Ударна } \\
\text { в'язкість } \\
\text { при } 0{ }^{\circ} \mathrm{C} \\
\mathrm{K} \mathrm{CU}, \\
\text { Дж/см' }\end{array}$ & $\begin{array}{c}\text { Робота } \\
\text { удару при } \\
-10^{\circ} \mathrm{C} \mathrm{KV}, \\
\text { Дж }\end{array}$ \\
\hline Спеціальні бронзи & 607 & 245 & 16 & - & - & - \\
\hline Спеціальні латуні & 460 & 176 & 20 & - & - & - \\
\hline Неіржавчі сталі & 637 & 510 & 15 & 40 & - & 21 \\
\hline Вуглецеві сталі & 412 & 235 & 20 & 30 & 39,2 & - \\
\hline
\end{tabular}

Таблиця 3. Хімічний склад вуглецевих сталей, які використовують для виготовлення гребних гвинтів за ГОСТ 997-88

\begin{tabular}{|c|c|c|c|c|c|c|c|c|}
\hline \multirow{3}{*}{ Марка сталі } & \multicolumn{8}{|c|}{ Вміст елементів, \% мас } \\
\hline & \multirow{2}{*}{$\mathrm{C}$} & \multirow{2}{*}{$\mathrm{Si}$} & \multirow{2}{*}{$\mathrm{Mn}$} & $\mathrm{Cr}$ & $\mathrm{Ni}$ & $\mathrm{Cu}$ & $\mathrm{S}$ & $\mathrm{P}$ \\
\hline & & & & \multicolumn{5}{|c|}{ не більше } \\
\hline $25 \Omega$ & $0,22-0,30$ & $0,20-0,52$ & $0,35-0,90$ & 0,30 & 0,30 & 0,30 & 0,045 & 0,04 \\
\hline 30Л & $0,27-0,35$ & $0,20-0,52$ & $0,40-0,90$ & 0,30 & 0,30 & 0,30 & 0,045 & 0,04 \\
\hline 35Л & $0,32-0,40$ & $0,20-0,52$ & $0,40-0,90$ & 0,30 & 0,30 & 0,30 & 0,045 & 0,04 \\
\hline
\end{tabular}


Вуглецеві сталі недорогі, але схильні до крихких руйнувань при низьких температурах, що неприпустимо для судів льодового плавання.

Гребні гвинти зі звичайної вуглецевої сталі, які застосовують на річних суднах, мають низьку зносостійкість, вони погано пручаються корозії і особливо кавітаційній ерозії. Вже до кінця першої навігації шорсткість їх поверхні досягає значень $\mathrm{Rz}=300-500$ мкм. Надалі це призводить до значних перевитрат палива і зниження швидкості судна за рахунок зростання моменту тертя і зниження коефіцієнта упору [6].

Гвинти, виготовлені з вуглецевих сталей, виходять 3 ладу внаслідок корозійного зносу через 6-18 місяців [2].

Експлуатація суден 3 такими гвинтами недоцільна і неекономічна. Проте в силу дефіцитності та коштовності кольорових металів і їх сплавів, а також, високої вартості неіржавчих сталей гвинти 3 вуглецевих сталей поки ще виготовляють, а з метою підвищення їх корозійної стійкості і втомної міцності іноді виконують електролітичне покриття лопатей спеціальними сплавами.

Для заміни абсолютно непридатної вуглецевої сталі у суднобудуванні поширення набули гвинти 3 литої неіржавчої сталі марок 08Х14НДЛ, 10Х14НДЛ, 08Х15Н4ДМЛ. Хіміч- ний склад сталей наведено в таблиці $4[1,5,7]$.

В порівнянні з іншими матеріалами, гребні гвинти з неіржавчих сталей мають більш високу міцність (див. табл. 2), характеризуються високими корозійно-втомними властивостями, високою антикавітаційною стійкістю, що дозволяє виготовляти їх лопати зменшеної товщини.

Неіржавча сталь має і свої недоліки. Поперше, ливарні властивості і оброблюваність неіржавчих сталей нижче, ніж у латуні та бронзи. По-друге, вартість неіржавчої сталі досить висока.

Більш придатними матеріалами для виготовлення гребних гвинтів є спеціальні сплави, зокрема латуні і бронзи. Відповідно до класифікації Міжнародної асоціації класифікаційних товариств (МАКТ) кольорові метали для виготовлення гребних гвинтів поділяють на чотири категорії з різним нижнім рівнем механічних властивостей (табл. 5) [8,9].

Основні марки латуні і бронзи, що застосовують для виготовлення гребних гвинтів в різних країнах, наведені в таблиці 6 [8].

Гребні гвинти 3 манганової латуні мають достатню корозійну стійкість в умовах дії протекції сталевого корпусу судна. Ливарні і корозійні властивості латуней в сто разів перевищують аналогічні властивості вуглецевих сталей.

Таблиця 4. Хімічний склад неіржавчих сталей , які використовують для гребних гвинтів $[1,5,7]$

\begin{tabular}{|c|c|c|c|c|c|c|c|c|c|}
\hline \multirow{2}{*}{ Марка сталі } & \multicolumn{9}{|c|}{ Вміст елементів, \% мас } \\
\hline & $\mathrm{C}$ & $\mathrm{Si}$ & $\mathrm{Mn}$ & $\mathrm{Ni}$ & Mo & $\mathrm{S}$ & $\mathrm{P}$ & $\mathrm{Cr}$ & $\mathrm{Cu}$ \\
\hline 08Х14НДЛ & $\begin{array}{c}\text { до } \\
0,08\end{array}$ & до 0,4 & $\begin{array}{c}0,50- \\
0,80\end{array}$ & $\begin{array}{c}1,20- \\
1,60\end{array}$ & - & $\begin{array}{c}\text { до } \\
0,025\end{array}$ & $\begin{array}{c}\text { до } \\
0,025\end{array}$ & $\begin{array}{c}13,0- \\
14,5\end{array}$ & $\begin{array}{c}0,80- \\
1,20\end{array}$ \\
\hline 10Х14НДЛ & до 0,1 & до 0,4 & $\begin{array}{c}0,30- \\
0,60\end{array}$ & $\begin{array}{c}1,20- \\
1,60\end{array}$ & - & $\begin{array}{c}\text { до } \\
0,030\end{array}$ & $\begin{array}{c}\text { до } \\
0,030\end{array}$ & $\begin{array}{c}13,5- \\
15,0\end{array}$ & $\begin{array}{c}1,20- \\
1,60\end{array}$ \\
\hline 08Х15Н4ДМЛ & $\begin{array}{c}\text { до } \\
0,08\end{array}$ & до 0,4 & $\begin{array}{c}1,00- \\
1,50\end{array}$ & $\begin{array}{c}3,50- \\
3,90\end{array}$ & $\begin{array}{c}0,30- \\
0,45\end{array}$ & $\begin{array}{c}\text { до } \\
0,025\end{array}$ & $\begin{array}{c}\text { до } \\
0,025\end{array}$ & $\begin{array}{c}14,0- \\
16,0\end{array}$ & $\begin{array}{c}1,00- \\
1,40\end{array}$ \\
\hline
\end{tabular}

Таблиця 5. Категорії мідних сплавів по МАКТ $[8,9]$

\begin{tabular}{|c|c|c|c|c|}
\hline \multirow[b]{2}{*}{$\begin{array}{c}\text { Позначення } \\
\text { сплаву }\end{array}$} & \multirow[b]{2}{*}{$\begin{array}{c}\text { Найменування } \\
\text { сплаву }\end{array}$} & \multicolumn{3}{|c|}{ Нижній рівень механічних властивостей } \\
\hline & & $\begin{array}{l}\text { Тимчасовий опір } \\
\text { розриву, } \sigma_{\text {в }} \text { МПа }\end{array}$ & $\begin{array}{c}\text { Умовна межа } \\
\text { плинності, } \sigma_{0,2}, \text { МПа }\end{array}$ & $\begin{array}{c}\text { Відносне } \\
\text { подовження, } \delta_{5}, \%\end{array}$ \\
\hline $\mathrm{Cu} 1$ & Манганова латунь Mn & 440 & 175 & 20 \\
\hline $\mathrm{Cu} 2$ & $\begin{array}{l}\text { Нікель-манганова } \\
\text { латунь NiMn }\end{array}$ & 440 & 175 & 20 \\
\hline $\mathrm{Cu} 3$ & $\begin{array}{c}\text { Нікель-алюмінієва } \\
\text { бронза NiAl }\end{array}$ & 590 & 245 & 16 \\
\hline $\mathrm{Cu} 4$ & $\begin{array}{c}\text { Манганова алюмінієва } \\
\text { бронза MnAl }\end{array}$ & 630 & 275 & 18 \\
\hline
\end{tabular}


Таблиця 6. Марки латуні і бронзи, що застосовують для гребних гвинтів [8]

\begin{tabular}{|c|c|c|c|}
\hline Країна, фірма & Манганова латунь & $\begin{array}{c}\text { Нікель- алюмінієві } \\
\text { бронзи NiAl }\end{array}$ & $\begin{array}{c}\text { Манганові алюмінієві } \\
\text { бронзи } \mathrm{MnAl}\end{array}$ \\
\hline Росія & $\begin{array}{c}\text { ЛМцЖ 55-3-1, ГОСТ } \\
1019-47 \\
\text { (ЛЦ40Мц3Ж } \\
\text { ОСТ5.9208-81) }\end{array}$ & $\begin{array}{c}\text { БрАЖН9-4-4 } \\
\text { (БрА9Ж4Н4 } \\
\text { ОСТ5.9208-81) }\end{array}$ & $\begin{array}{l}\text { Нева-60 } \\
\text { Нева-70 }\end{array}$ \\
\hline Англія, «Стоун» & Стоун (HTBI) & $\begin{array}{l}\text { Нікаліум } \\
\text { АВ-2 }\end{array}$ & $\begin{array}{c}\text { Новостон (CM1) Супе- } \\
\text { рстон } 70 \text { Соностон } \\
(50 \mathrm{MД}) \\
\end{array}$ \\
\hline Голандія & Ліма бронза & Куніал бронза 66 & $\begin{array}{c}\text { Ліндрунель } 66 \text { Ліндру- } \\
\text { нель } 905\end{array}$ \\
\hline Італія, «Ансальдо» & Бронза A1-М & Ніальма & - \\
\hline $\begin{array}{l}\text { Франція, «Сосьєте } \\
\text { Нантіз» }\end{array}$ & - & Нантіал UAR19-QR60 & Мангал 99 \\
\hline $\begin{array}{l}\text { Німеччина, «Теодор } \\
\text { Цайзе» }\end{array}$ & $\begin{array}{l}\text { G-SM57F45 } \\
\text { G-SMN15 } \\
\text { G-SMN17 }\end{array}$ & $\begin{array}{c}\text { G-NiB F60 } \\
\text { Алкунік } \\
\text { NiAlBz(DMR) }\end{array}$ & $\begin{array}{c}\text { G-MnAlBzFe45 } \\
\text { Al-MnBzl3 } \\
\text { Куманал } \\
\text { Куманал OZE1 }\end{array}$ \\
\hline $\begin{array}{l}\text { США, } \\
\text { «Болдуін Ліма Гамі- } \\
\text { льтон», «Інтер- } \\
\text { нейшнл Нікель ком- } \\
\text { пані», } \\
\text { «Бетліхем Стіл Кор- } \\
\text { порейшн», } \\
\text { «Неві Ярд» }\end{array}$ & QQB-726C & $\begin{array}{c}\text { Ніаліт } \\
\text { Нібрал } \\
\text { Куніал } \\
\text { - }\end{array}$ & $\begin{array}{l}\text { ASS Type } 5 \\
\begin{array}{c}- \\
- \\
-\end{array}\end{array}$ \\
\hline $\begin{array}{l}\text { Японія, «Нікашіба } \\
\text { Міцубісі», «Амагаса- } \\
\text { ки» }\end{array}$ & $\begin{array}{l}\text { ASB2 } \\
- \\
\text { ASB8 } \\
\text { ASB3 }\end{array}$ & $\begin{array}{c}\text { ASB4 и ASB6 } \\
\text { А1ВС3 } \\
\text { Міцубісі } \\
-\end{array}$ & $\begin{array}{c}- \\
\text { ASB7 } \\
- \\
-\end{array}$ \\
\hline
\end{tabular}

Для виготовлення гребних гвинтів найбільш часто використовують манганову латунь марки ЛЦ40Мц3Ж, хімічний склад якої наведено в таблиці 7 [10].

Манганові латуні задовільно зварюються різними способами, що дуже цінно при виготовленні гребних гвинтів і їх ремонті. Висока пластичність манганових латуней дозволяє порівняно легко здійснювати правку лопатей при їх нагріванні до температур $550-700^{\circ} \mathrm{C}$ [11].

Манганові латуні вигідно відрізняються від інших сплавів на мідній основі для гребних гвинтів і з економічної точки зору. Однак, по міцності та експлуатаційної стійкості ці сплави виявилися малопридатними для гребних гвинтів суден окремих типів [11]. Так, гребні гвинти 3 латуні марки ЛЦ40Мц3Ж, особливо при роботі в тропіках під час відсутності протекторного або катодного захисту, мають схильність до виділення зі сплаву цинку. В результаті цього під час експлуатації знижується міцність латуні і в гвинтах з'являються тріщини [12].

Основні недоліки манганових латуней наступні: схильність до корозійного розтріскування, відносно невисокі показники міцності, корозійно-втомна міцність і ерозійна стійкість і порівняно висока питома вага [11]. Через ці недоліки виникає ряд проблем, від вирішення яких залежить надійність гребних гвинтів при експлуатації. Ці проблеми пов'язані з природою сплаву і тому можуть бути вирішені тільки в разі його заміни.

Підвищення міцності гребних гвинтів при одночасному збереженні необхідної корозійної стійкості привела до створення спеціальних алюмінієвих латуней. Хімічний склад деяких високоміцних алюмінієвих латуней, які використовують в країнах пострадянського простору для виготовлення гребних гвинтів, надано в таблиці 8 [11]. 
Таблиця 7. Хімічний склад сплаву ЛЦ40МцЗЖ, ГОСТ 17711- 93

\begin{tabular}{|c|c|c|c|c|c|c|c|c|c|c|c|}
\hline \multicolumn{10}{|c|}{ Вміст елементів,\% мас } \\
\hline $\mathrm{Fe}$ & $\mathrm{Si}$ & $\mathrm{Mn}$ & $\mathrm{Ni}$ & $\mathrm{P}$ & $\mathrm{Al}$ & $\mathrm{Cu}$ & $\mathrm{Pb}$ & $\mathrm{Zn}$ & $\mathrm{Sb}$ & $\mathrm{Sn}$ & Домішок \\
\hline $0,5-$ & до & $3,0-$ & до & до & до & $53,3-$ & до & $34,8-$ & до & до & \multirow{2}{*}{ всього 1,7} \\
1,5 & 0,2 & 4,0 & 0,5 & 0,05 & 0,6 & 58,8 & 0,5 & 43,5 & 0,1 & 0,5 & \\
\hline
\end{tabular}

Таблиця 8. Хімічний склад високоміцних алюмінієвих латуней для виготовлення гребних гвинтів [11]

\begin{tabular}{|l|c|c|c|c|c|}
\hline \multirow{2}{*}{ Марка сплаву } & \multicolumn{5}{|c|}{ Вміст елементів,\% мас } \\
\cline { 2 - 6 } & $\mathrm{Cu}$ & $\mathrm{Al}$ & $\mathrm{Mn}$ & $\mathrm{Fe}$ & $\mathrm{Zn}$ \\
\hline ЛАМцЖ 67-5-2-2 & $67-70$ & $5-6$ & $2-3$ & $2-3$ & Решта \\
\hline ЛАМцЖ 68-5,5-2-2 & $68-70$ & $5,4-5,8$ & $2-3$ & $2-3$ & Решта \\
\hline
\end{tabular}

Легування латуні алюмінієм призвело до різкого підвищення характеристик міцності (табл. 9), деякого підвищення корозійної стійкості, корозійної втоми і стійкості проти руйнувань під впливом кавітації і зниження питомої ваги. Алюмінієві латуні перевершують манганові по корозійно-ерозійної стійкості в морській воді. Зварювання алюмінієвих латуней не викликає особливих труднощів.

Однак, слід зазначити, що ливарні властивості алюмінієвих латуней гірші, ніж мангано- вих. Це пояснюється наявністю в їх складі алюмінію, що підсилює в процесі плавки і литва утворення плівок оксидів. Виникаючі на поверхні сплаву плівки оксидів алюмінію ускладнюють видалення 3 нього розчинених газів. Також легування алюмінієм значно погіршує пластичність. Тому на сьогодні гвинти 3 алюмінієвих латуней не знаходять широкого застосування для великих суден i використовують лише в малому суднобудуванні [12].

Таблиця 9. Механічні властивості латуней, що застосовують для виготовлення гребних гвинтів [10,11]

\begin{tabular}{|l|c|c|}
\hline \multicolumn{1}{|c|}{ Марка сплаву } & $\begin{array}{c}\text { Тимчасовий опір розриву, } \\
\sigma_{\mathrm{B}}, \text { МПа }\end{array}$ & $\begin{array}{c}\text { Відносне подовження, } \\
\delta_{5}, \%\end{array}$ \\
\hline ЛЦ40Мц3Ж & 480 & 20 \\
\hline ЛАМцЖ 67-5-2-2 & 620 & 12 \\
\hline ЛАМцЖ 68-5,5-2-2 & 550 & 16 \\
\hline
\end{tabular}

Необхідність підвищення корозійновтомної міцності, ерозійної стійкості гребних гвинтів, зниження їх ваги для забезпечення надійності роботи діючого пристрою сучасних судів призвела до розробки і впровадження у виробництво високоміцних корозійностійких бронз.

Найбільш перспективними і якісними матеріалами для виготовлення сучасних гребних гвинтів $є$ нікель-алюмінієві, і в ще більшому ступені манган-алюмінієві бронзи.

Ці сплави, в якості матеріалу для виготовлення гребних гвинтів, мають наступні переваги в порівнянні з латунями [11]:

- за рахунок меншої питомої ваги, більш високих значень межі плинності, тимчасового опору розриву, відношення міцності до ваги i корозійної витривалості може бути істотно зни- жена вага гребного гвинта. Зменшення ваги гребного гвинта забезпечує зниження зносу підшипників валопроводу, а також економію матеріалу;

- за рахунок більш високої стійкості алюмінієвих бронз проти корозії і ерозії в морській воді істотно сповільнюється процес утворення шорсткості на поверхні лопатей. Більш високий рівень міцності алюмінієвої бронзи дозволяє зменшувати товщини лопатей на $8-10 \%$. Ці переваги забезпечують підвищення коефіцієнта корисної дії гребних гвинтів приблизно на $2 \%$, що створює можливість істотної економії палива;

- відсутність у алюмінієвої бронзи схильності до корозійного розтріскування в морській воді і на повітрі і в 1,5-2,0 рази вищий рівень корозійної витривалості. Тобто, при правильно- 
му розрахунку гребного гвинта на міцність i правильної технології його виготовлення, практично виключається можливість поломок його лопатей з утворенням зламів втоми;

- підвищується упор гвинта при однаковій потужності суднових двигунів;

- момент інерції гребного гвинта знижується приблизно на 15 - $19 \%$;

- 3 високоміцних алюмінієвих бронз можна виготовляти досить надійні гребні гвинти для плавання в льодових умовах. Це спрощує експлуатацію суден при змішаному плаванні в чистих водах і льодових умовах. Відпадає необхідність зміни штатних гребних гвинтів з бронзи на льодові сталеві гвинти. Гвинти 3 алюмінієвонікелевої бронзи цілком можуть замінити гребні гвинти 3 конструкційної і неіржавчої сталі при плаванні в льодових умовах. Пошкодження від удару об лід у гребних гвинтів 3 манганалюмінієвої бронзи значно менше, ніж у гребних гвинтів 3 манганової латуні;
- внаслідок більш високої корозійної стійкості в морській воді гребні гвинти 3 алюмінієвої бронзи менш схильні до корозійних руйнувань у випадках порушень протекторного захисту;

- більш висока стійкість алюмінієвих бронз в порівнянні зі спеціальними латунями проти гідроабразивного зносу підвищує довговічність гребних гвинтів при їх експлуатації в водах, що містять значну кількість мулу і піску;

- незважаючи на більш високу вартість виробництва ( на $25-35 \%$ ), гребні гвинти 3 алюмінієво-нікелевої бронзи, внаслідок більш високої стійкості і надійності, дешевше латунних в експлуатації майже на $21-33 \%$, без урахування прибутку від економії палива за рахунок більш високого КПД.

Хімічний склад та механічні властивості бронз, що застосовують в країнах пострадянського простору для виготовлення гребних гвинтів представлені в таблиці 10 [9, 13, 14].

Таблиця 10. Хімічний склад бронз для гребних гвинтів [9, 13, 14]

\begin{tabular}{|c|c|c|c|c|c|c|c|c|c|}
\hline \multirow{3}{*}{ Марка сплаву } & \multicolumn{6}{|c|}{ Вміст елементів,\% мас } & \multicolumn{3}{|c|}{ Механічні властивості } \\
\hline & \multirow[t]{2}{*}{$\mathrm{Al}$} & \multirow[t]{2}{*}{ Mn } & \multirow[t]{2}{*}{$\mathrm{Ni}$} & \multirow[t]{2}{*}{$\mathrm{Fe}$} & \multirow[t]{2}{*}{$\mathrm{Zn}$} & \multirow[t]{2}{*}{$\mathrm{Cu}$} & $\begin{array}{c}\text { Тимчасо- } \\
\text { вий опір } \\
\text { розриву, } \sigma_{\text {в }} \text {, } \\
\text { МПа }\end{array}$ & $\begin{array}{c}\text { Умовна } \\
\text { межа } \\
\text { плинності, } \\
\sigma_{0,2}, \text { МПа }\end{array}$ & $\begin{array}{c}\text { Відносне } \\
\text { подовження, } \\
\delta_{5}, \%\end{array}$ \\
\hline & & & & & & & \multicolumn{3}{|c|}{ не менше } \\
\hline БрА9Ж4Н4 & $\begin{array}{c}9,0- \\
9,8\end{array}$ & $\begin{array}{c}0,5- \\
1,2\end{array}$ & $\begin{array}{c}4,0- \\
5,0\end{array}$ & $\begin{array}{c}4,0- \\
5,0\end{array}$ & - & $\begin{array}{l}\text { Реш- } \\
\text { та }\end{array}$ & 607 & 245 & 16 \\
\hline БрА7Мц14Ж3Н2 & $\begin{array}{l}7,4- \\
7,9\end{array}$ & $\begin{array}{c}13,0- \\
15,0\end{array}$ & $\begin{array}{l}1,5- \\
2,5\end{array}$ & $\begin{array}{l}2,5- \\
3,5\end{array}$ & - & $\begin{array}{c}\text { Реш- } \\
\text { та }\end{array}$ & 686 & 294 & 18 \\
\hline Нева 60 & $\begin{array}{c}6,6- \\
7,0\end{array}$ & $\begin{array}{l}14,0- \\
16,5 \\
\end{array}$ & $\begin{array}{l}1,5- \\
2,5\end{array}$ & $\begin{array}{l}2,5- \\
3,5\end{array}$ & $\begin{array}{l}1,5- \\
2,5\end{array}$ & $\begin{array}{c}\text { Реш- } \\
\text { та }\end{array}$ & 590 & 275 & 20 \\
\hline $\begin{array}{l}\text { Нева } 70 \\
\text { (БрА7Мц15Ж3Н2Ц2) }\end{array}$ & $\begin{array}{l}6,6- \\
7,5\end{array}$ & $\begin{array}{l}14,0- \\
15,5\end{array}$ & $\begin{array}{l}1,5- \\
2,5\end{array}$ & $\begin{array}{l}2,5- \\
3,5\end{array}$ & $\begin{array}{l}1,5- \\
2,5\end{array}$ & $\begin{array}{l}\text { Реш- } \\
\text { та }\end{array}$ & 685 & 295 & 16 \\
\hline
\end{tabular}

Нікель-алюмінієві бронзи, які застосовують для відливання гребних гвинтів, $є$ п'ятикомпонентними сплавами, до складу яких зазвичай входять мідь, алюміній, нікель, залізо і манган. Ці бронзи мають порівняно складну структуру, від якої значною мірою залежать їх механічні, фізичні і технологічні властивості, а також стійкість проти корозії. На структуру алюмінієвонікелевих бронз впливають багато факторів, у тому числі головні - хімічний склад і умови охолодження виливків у формах [11].

Гребні гвинти 3 нікель-алюмінієвої бронзи, маючи підвищену стійкість проти корозійних $\mathrm{i}$ ерозійних руйнувань, тривалий час зберігають первісну чистоту поверхні лопатей. Крім того, ця бронза практично не має схильності до корозійного розтріскування і після нагрівання не вимагає термообробки.

Одним 3 основних недоліків цього сплаву $\epsilon$ поява крихкості при нагріванні від 200 до $500{ }^{\circ} \mathrm{C}$. При цьому при температурі $360-400{ }^{\circ} \mathrm{C}$ спостерігається зона максимальної крихкості. Якщо лопать гребного гвинта 3 такої бронзи нагріти в межах цього інтервалу температур, то вона втрачає свої пластичні властивості (рис. 1) і при прикладенні навантаження (наприклад, при правці) може зламатися. Після збільшення температури до $700{ }^{\circ} \mathrm{C}$ і вище пластичні властивості цього матеріалу підвищуються $[12,13]$. 


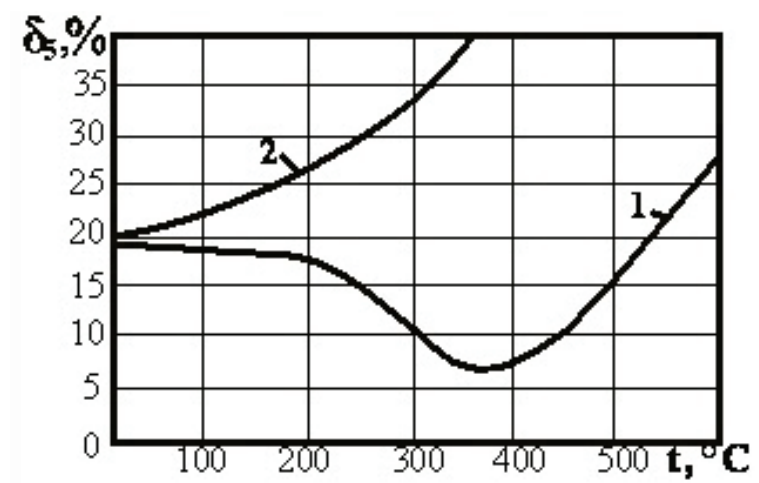

Рис. 1. Пластичні властивості нікельалюмінієвих і манган-алюмінієвих бронз [13]: 1 - відносне подовження нікель-алюмінієвих бронз, 2 - відносне подовження манган-алюмінієвих бронз

До інших недоліків слід віднести складність виготовлення литих гвинтів через гірші, ніж у латуней, ливарні властивості, а також схильність до газонасичення і інтенсивного окислення в процесі заливки. Тому плавку доводиться вести в спеціальних індукційних електропечах великої місткості [12].

Іншим напрямком у створенні високоміцних алюмінієвих бронз для гребних гвинтів слід вважати розробку манган-алюмінієвих бронз 3 високим вмістом мангану. В цих бронзах вдалося усунути недоліки нікель-алюмінієвих і одночасно зберегти і розвинути їх основні позитивні якості.

Доцільність застосування манганалюмінієвих бронз для литих гребних гвинтів замість алюмінісво-нікелевої бронзи продиктовано наступним [11]:

- необхідністю знизити температуру плавлення сплаву, кількості газів, які розчиняються в рідкому металі;

- усуненням окрихчення сплаву при підвищених температурах, що істотно ускладнює ремонт лопатей гребних гвинтів шляхом гарячої правки (манган-алюмінієві бронзи не схильні до окрихчення при нагріванні про що свідчать залежності на рис. 1).

Аналіз вищевикладеного свідчить про те, що алюмінієві бронзи є найбільш перспективним матеріалом для виготовлення гребних гвинтів, тому що вони технологічні, мають високу корозійну стійкість на повітрі, в морській воді і в деяких агресивних середовищах, високий опір кавітації.

Слід зазначити, що розвиток сучасного суднобудування диктує підвищення експлуатацій- ної надійності і довговічності роботи гребних гвинтів. У зв'язку з цим $є$ актуальним вдосконалення і розробка нових складів бронз. Одним 3 перспективних напрямків у цій галузі є введення в алюмінієві бронзові сплави, в якості легуючого елемента, олова, що дозволяє підвищити корозійну стійкість і опір абразивному зноcy [15].

\section{Висновки}

За результатами аналізу встановлено, що найбільш доцільним матеріалом для виготовлення гребних гвинтів 3 точки зору сукупності показників конструкційної міцності, зносостійкості та експлуатаційної надійності є алюмінієві бронзи.

На підставі аналізу нормативно-технічних вимог до алюмінієвих бронз, які стандартно використовують для виробництва гребних гвинтів, доведена перспективність додаткового їх легування манганом у раціональній кількості, що дозволяє підвищити, характеристики міцності.

Зазначено, що введення в алюмінієві бронзові сплави, які застосовують для виготовлення гвинтів, в якості легуючого елемента, олова дозволить підвищити їх корозійну стійкість і опір абразивному зносу.

\section{Бібліографічний список}

1. Богораз И. И., Кауфман И. М. Производство гребных винтов : справочник. Ленинград: Судостроение, 1978. 192 с.

2. Материалы для изготовления гребных винтов. URL: https://poznayka.org/s86461t1.html.

3. Изготовление гребных винтов. URL: https://helpiks.org/9-34947.html.

4. ГОСТ 8054-81. Винты гребные металлические. Общие технические условия. [Дата введения 1981-07-01]. Москва : ИПК Издательство стандартов, 1981. 21 с. (Межгосударственный стандарт).

5. ГОСТ 977-88. Отливки стальные. Общие технические условия. [Дата введения 1990-0101]. Москва: ИПК Издательство стандартов, 1988. 35 с. (Межгосударственный стандарт).

6. Гребной винт судна с расчетом и изготовлением. URL: http://dvinko.ru/services/ izgotovlenie-grebnyh-vintov.

7. ГОСТ 2176-77. Отливки из высоколегированной стали со специальными свойствами. Общие технические условия. [Дата введения 
1979-01-01]. Москва: Государственный стандарт, $1977.31 \mathrm{c}$.

8. Российский морской регистр судоходства. Методические рекомендации по техническому наблюдению за ремонтом морских судов. НД № 2-039901-005. Санкт-Петербург, 2018. $146 \mathrm{c}$.

9. ОСТ5Р.9782-2004. Винты гребные из сплавов на медной основе. Исправление дефектов и повреждений. Типовой технологический процесс. [Дата введения 2004-01-01], 2004. 459 с. (Стандарт судостроения).

10. ГОСТ 17711-93. Сплавы медноцинковые (латуни) литейные. Марки. [Дата введения 1995-01-01]. Минск : ИПК Издательство стандартов, 2002. 6 с. (Межгосударственный стандарт).

11. Соколов Н. Н., Лазаренко С. П., Журавлев В. И. Гребные винты из алюминиевой бронзы. Ленинград : Судостроение, 1971. 288 с.

12. Емельянов Н. Ф. Ходкость водоизмещающих морских судов: учебное пособие. Владивосток : Дальрыбвтуз, 2004. 249 с.

13. Материалы, применяемые для изготовления гребных винтов. веб-сайт. URL: http://vlpacific.ru/?module $=$ news\&action $=$ article\&i $\mathrm{d}=50$

14. ГОСТ 493-79. Бронзы безоловянные литейные. [Дата введения 1980-01-01.], 1979, 3 с. (Межгосударственный стандарт).

15. Soares D. F., Abreu M., Barros D., Castro F. Experimental study of the $\mathrm{Cu}-\mathrm{Al}-\mathrm{Sn}$ phase equilibria, close to the copper zone. Journal of Mining and Metallurgy, Section B: Metallurgy. 2017. Vol. 53. Issue (3). P. 209-213.

\section{References}

1. Bogoraz, I. I., \& Kaufman, I.M. (1978). Proizvodstvo grebnykh vintov: spravochnik. Leningrad: Sudostroenie

2. Materialy dlia izgotovleniia grebnykh vintov. Retrieved from: https://poznayka.org/ s86461t1.html

3. Izgotovlenie grebnykh vintov. Retrieved from: https://helpiks.org/9-34947.html
4. GOST 8054-81. (1981). Vinty grebnye metallicheskie. Obshchie tekhnicheskie usloviia. [Data vvedeniia 1981-07-01]. Moskva: IPK Izdatelstvo standartov. (Mezhgosudarstvennyi standart)

5. GOST 977-88. (1988). Otlivki stalnye. Obshchie tekhnicheskie usloviia. [Data vvedeniia 1990-01-01]. Moskva: IPK Izdatelstvo standartov. (Mezhgosudarstvennyi standart)

6. Grebnoi vint sudna s raschetom i izgotovleniem. Retrieved from: http://dvinko.ru/services/ izgotovlenie-grebnyh-vintov

7. GOST 2176-77. (1977). Otlivki iz vysokolegirovannoi stali so spetsialnymi svoistvami. Obshchie tekhnicheskie usloviia. [Data vvedeniia 197901-01]. Moskva: Gosudarstvennyi standart

8. Rossiiskii morskoi registr sudokhodstva. Metodicheskie rekomendatsii po tekhnicheskomu nabliudeniiu za remontom morskikh sudov. ND № 2-039901-005. Sankt-Peterburg (2018)

9. OST5R.9782-2004. (2004). Vinty grebnye iz splavov na mednoi osnove. Ispravlenie defektov $i$ povrezhdenii. Tipovoi tekhnologicheskii protsess. [Data vvedeniia 2004-01-01]. (Standart sudostroeniia)

10. GOST 17711-93. (2002). Splavy mednotsinkovye (latuni) liteinye. Marki. [Data vvedeniia 1995-01-01]. Minsk: IPK Izdatelstvo standartov. (Mezhgosudarstvennyi standart)

11. Sokolov, N. N., Lazarenko, S. P., \& Zhuravlev, V. I. (1971). Grebnye vinty iz aliuminievoi bronzy. Leningrad: Sudostroenie

12. Emelianov, N. F. (2004). Khodkost vodoizmeshchaiushchikh morskikh sudov: uchebnoe posobie. Vladivostok: Dalrybvtuz

13. Materialy, primeniaemye dlia izgotovleniia grebnykh vintov. Retrieved from: $\mathrm{http}: / / \mathrm{vlpacific} . \mathrm{ru} /$ ?module=news\&amp;action=artic le\&amp;id $=50$

14. GOST 493-79. (1979). Bronzy bezoloviannye liteinye. [Data vvedeniia 1980-01-01.]. (Mezhgosudarstvennyi standart)

15. Soares, D. F., Abreu, M., Barros, D., \& Castro, F. (2017). Experimental study of the Cu-AlSn phase equilibria, close to the copper zone. Journal of Mining and Metallurgy, Section B: Metallurgy, 53(3), 209-213

Кімстач Тетяна Володимирівна, старший викладач кафедри термічної обробки металів, Національна металургійна академія України (м. Дніпро, Україна). ORCID ID: 0000-0002-8993-201X. E-mail: 1375tatyana@gmail.com

Узлов Костянтин Іванович, професор, доктор технічних наук, професор кафедри матеріалознавства, Національна металургійна академія України (м. Дніпро, Україна). ORCID ID: 0000-0003- 
0744-9890. E-mail: konst.uzlov@gmail.com

Реп'ях Сергій Іванович, доктор технічних наук, професор кафедри ливарного виробництва, Національна металургійна академія України (м. Дніпро, Україна). ORCID ID: 0000-0003-0203-4135. Email: 123rs@ua.fm

Солоненко Людмила Ігорівна, доцент, кандидат технічних наук, доцент кафедри технології та управління ливарними процесами, Одеський національний політехнічний університет (м. Одеса, Україна). ORCID ID: 0000-0003-2092-8044. E-mail: solonenkoli14@gmail.com

\section{АНАЛІЗ НОРМАТИВНИХ ВИМОГ ДО МАТЕРІАЛУ ДЛЯ ВИГОТОВЛЕННЯ ГРЕБНИХ ГВИНТІВ}

Мета. На підставі порівняльного аналізу нормативних вимог до використовуваних матеріалів визначити ефективні напрями удосконалення складів та технології обробки сплавів для виготовлення гребних гвинтів морських суден. 3 урахуванням одержаних даних, встановити перспективні матеріали та шляхи підвищення надійності і довговічності роботи виробів для судноплавства.

Методика. В роботі використано метод зіставного аналізу з метою обгрунтування перспективи використання спеціальних бронз для виготовлення деталей, що аналізуються.

Результати. Встановлено, що найбільш доцільним матеріалом для виготовлення гребних гвинтів 3 точки зору сукупності показників конструкційної міцності, зносостійкості та експлуатаційної надійності є алюмінієві бронзи додатково леговані манганом та оловом.

Наукова новизна. Новизна технічного рішення полягає в тому, що на підставі аналізу нормативно-технічних вимог до алюмінієвих бронз, які стандартно використовують для виробництва гребних гвинтів, відмічена перспективність додаткового їх легування оловом, що дозволить підвищити корозійну стійкість та опір абразивному зносу, а також манганом, у раціональній кількості, з метою підвищення міцності.

Практична цінність. Надана актуальна інформація щодо проблеми підвищення надійності та довговічності роботи гребних гвинтів, одним з методів вирішення якої є цілеспрямований вибір матеріалу для їх виготовлення. Запропоновані у якості ефективних матеріалів для виготовлення виконавчих рушійних елементів морських суден алюмінієві бронзи з аргументовано обгрунтованою кількістю легуючих домішок.

Ключові слова: нормативні вимоги, стандарт, гребні гвинти, легуючі елементи, механічні і технологічні властивості, корозійна стійкість.

Kimstach Tetiana Volodymyrivna, Senior Instructor of the Department of heat treatment of metals, National Metallurgical Academy of Ukraine (Dnipro, Ukraine). ORCID ID: 0000-0002-8993-201X. E-mail: 1375tatyana@gmail.com

Uzlov Konstantin Ivanovich, Doctor of Technical Science, Professor of the Department of materials science, National Metallurgical Academy of Ukraine (Dnipro, Ukraine). ORCID ID: 0000-0003-0744-9890. E-mail: konst.uzlov@gmail.com

Repyakh Sergei Ivanovich, Doctor of Technical Science, Professor of the Department of Foundry, National Metallurgical Academy of Ukraine (Dnipro, Ukraine). ORCID ID: 0000-0003-0203-4135. E-mail: 123rs@ua.fm

Solonenko Lyudmila Igorivna, Candidate of Technical Sciences, Senior Lecturer of the Department of Technology and Management of Foundry Processes, Odessa National Polytechnic University (Odessa, Ukraine). ORCID ID: 0000-0003-2092-8044. E-mail: solonenkoli14@gmail.com

\section{MATERIALS FOR MARINE PROPELLERS MANUFACTURING NORMATIVE REQUIREMENTS ANALYSIS}

Purpose. On the basis of regulatory requirements for used materials comparative analysis, effective directions for alloys compositions and processing technologies improving for sea-going ships propellers manufacturing have to be determined. Taking into account the data obtained, prospective materials and measures for shipping products reliability and durability improving have to be established. 
Methods. Object of this analysis has been up-to-date normative and technical database concerning standard and advanced materials for sea vessels propellers manufacturing compositions and production technologies. Comparative analysis method has been used in order to substantiate the prospects of special bronzes for analyzed parts manufacturing implementation.

Results. From set of indicators of structural strength, wear resistance and operational reliability point of view it has been established that the most appropriate material for propellers manufacturing are aluminum bronzes additionally alloyed with manganese and tin.

Originality. Technical solution novelty lies in the fact that on the basis of normative and technical requirements for aluminum bronzes analyses, which are standardly used for propellers production, the prospects of their additional alloying with tin have been proved. This contributes to corrosion and abrasion resistance improvement. Alloying with manganese in rational amount provides strength characteristics increasing.

Practical implications. Up-to-date information concerning the problem of propellers reliability and durability increasing has been provided. One of the methods for this problem solving is material for their manufacturing targeted choosing. Aluminum bronzes with reasonably justified amount of alloying components as effective materials for sea vessels executive propulsion elements manufacturing have been proposed.

Key words: normative requirement, standard, marine propellers, alloying elements, mechanical and technological properties, corrosion resistance.

Кимстач Татьяна Владимировна, старший преподаватель кафедры термической обработки металлов, Национальная металлургическая академия Украины (Днепр, Украина). ORCID ID: 0000-00028993-201X. E-mail: 1375tatyana@gmail.com

Узлов Константин Иванович, профессор, доктор технических наук, профессор кафедры материаловедения, Национальная металлургическая академия Украины (Днепр, Украина). ORCID ID: 0000-0003-0744-9890.E-mail: konst.uzlov@gmail.com

Репях Сергей Иванович, доктор технических наук, профессор кафедры литейного производства, Национальная металлургическая академия Украины (Днепр, Украина). ORCID ID: 0000-00030203-4135. E-mail: 123rs@ua.fm

Солоненко Людмила Игоревна, доцент, кандидат технических наук, доцент кафедры технологий и управления литейными процессами, Одесский национальный политехнический университет (Одесса, Украина). ORCID ID: 0000-0003-2092-8044. E-mail: solonenkoli14@gmail.com

\section{АНАЛИЗ НОРМАТИВНЫХ ТРЕБОВАНИЙ К МАТЕРИАЛАМ ДЛЯ ИЗГОТОВЛЕНИЯ ГРЕБНЫХ ВИНТОВ}

Цель. На основании сравнительного анализа нормативных требований к используемым материалам определить эффективные направления усовершенствования составов и технологии обработки сплавов для изготовления гребных винтов морских судов. С учетом полученных данных, установить перспективные материалы и пути повышения надежности и долговечности работы изделий для судоходства.

Методика. В работе использован метод сопоставительного анализа с целью обоснования перспективы использования специальных бронз для изготовления анализируемых деталей.

Результаты. Установлено, что наиболее целесообразным материалом для изготовления гребных винтов с точки зрения совокупности показателей конструкционной прочности, износостойкости и эксплуатационной надежности являются алюминиевые бронзы дополнительно легированные марганцем и оловом.

Научная новизна. Новизна технического решения заключается в том, что на основании анализа нормативно-технических требований к алюминиевым бронзам, которые стандартно используют для производства гребных винтов, отмечена перспективность дополнительного их легирования оловом, что позволяет повысить коррозионную стойкость и сопротивление абразивному износу, а также марганцем, в рациональном количестве, с целью повышения прочностных характеристик.

Практическая ценность. Предоставлена актуальная информация, касающаяся проблемы повышения надежности и долговечности работы гребных винтов, одним из методов решения которой яв- 
ляется целенаправленный выбор материала для их изготовления. Предложены, в качестве эффективных материалов для изготовления исполнительных движущих элементов морских судов, алюминиевые бронзы с аргументировано обоснованным количеством легирующих примесей.

Ключевые слова: нормативные требования, стандарт, гребные винты, легирующие элементы, механические и технологические свойства, коррозионная стойкость.

Рукопис надійшов 18.06.2020 p. 